\title{
Sucrose hydrolysis by invertase using a membrane reactor: effect of membrane cut-off on enzyme performance
}

\author{
Francesco Di Addezio', Ester Junko Yoriyaz², Maria Cantarella', Michele Vitolo, ${ }^{2}$ * \\ ${ }^{1}$ Department of Chemical Engineering, University of L'Aquila, Italy, ${ }^{2}$ Department of Biochemical and Pharmaceutical \\ Technology, Faculty of Pharmaceutical Sciences, University of São Paulo, São Paulo, Brazil
}

\begin{abstract}
Sucrose hydrolysis by invertase [EC.3.2.1.26] produces inverted sugar syrup, an ingredient mainly used in the food industry. To properly catalyze hydrolysis, the enzyme should be reused after this reaction. It is advisable to maintain constant activity over a considerable period. Thus, sucrose hydrolysis was performed in a membrane bioreactor - a continuously stirred tank reactor coupled with an ultrafiltration membrane (UFM) which provides good diffusion and high activity per unit volume. Molecular weight cut-off for soluble invertase UFMs was up to $100 \mathrm{kDa}$. This study focused on the role of UFM invertase cut-off as it is the main element in the process. We demonstrated that both the cut-off and chemical nature of the UFM affected specific invertase activity.
\end{abstract}

Uniterms: Invertase. Membrane Reactor.Sucrose/hydrolysis.

\begin{abstract}
A hidrólise da sacarose através da invertase [EC.3.2.1.26] gera xarope de açúcar invertido, que é usado principalmente como ingrediente na indústria alimentícia. Para ter-se uma hidrólise satisfatória, a enzima deve ser reaproveitada após a reação. É desejável que sua atividade seja mantida constante durante um período considerável de reação. A hidrólise da sacarose foi realizada em um reator com membrana (RM) - que é um reator continuamente agitado acoplado a uma membrana de ultrafiltração (MUF) -, porque apresenta efeitos mínimos de difusão e elevada atividade por unidade de volume. O corte molecular da MUF utilizada para reter a invertase solúvel dentro do MR foi de até $100 \mathrm{kDa}$. Como a invertase é o elemento principal deste processo, este trabalho foi focado no papel do corte molecular da MUF na sua atividade. O corte molecular e a natureza química da membrana-UF mostraram afetar a atividade específica da invertase.
\end{abstract}

Unitermos: Invertase. Reator de Membrana. Sacarose/hidrólise.

\section{INTRODUCTION}

Inverted sugar syrup from sucrose hydrolysis is an ingredient used in the food industry. It may also be a source of carbon in fermentation processes. The syrup can be used in food formulation either as a sweetener or a moistener; it also acts as a viscosity, freezing point and water activity reducer of aqueous solutions. As a food component, the syrup colors and aromatizes the product through the Maillard reaction as well as avoiding the crystallization of other formula components.

Sucrose hydrolysis can be catalyzed by hydrochloric

\footnotetext{
*Correspondence: M. Vitolo. Departamento de Tecnologia Bioquímico-Farmacêutica, Faculdade de Ciências Farmacêuticas - USP. Av. Prof. Lineu Prestes, 580, 05315-970 - São Paulo - SP, Brasil. Email: michenzi@usp.br
}

acid or by an enzyme such as invertase or $\alpha$-glucosidase. Despite acidic sucrose hydrolysis being viable for obtaining syrup, the enzymatic process is preferable being a mild reaction $\left(4.5<\mathrm{pH}<5.0\right.$ and $30^{\circ} \mathrm{C}<\mathrm{T}<$ $50{ }^{\circ} \mathrm{C}$ ) (Vitolo, 2004). Moreover, there is no undesirable byproduct formation (Tomotani, Vitolo, 2010). Invertase was chosen for this study because it is inexpensive and abundantly available. In order to properly catalyze the hydrolysis, the enzyme should be reused; it is advisable to keep activity constant over a considerable reaction period. Enzyme recovery is best achieved through immobilization which increases overall process cost due to the need for specific reagents, a carrier, and equipment; enzyme catalytic capacity sometimes diminishes lengthening reaction duration (Nisha et al., 2012). Thus, soluble invertase in a so-called membrane bioreactor (MBR) 
would be an alternative for hydrolyzing sucrose.

An MBR is a continuous stirred tank reactor (CSTR) with an ultra-filtration membrane (UFM) set in its bottom (Tomotani, Neves, Vitolo, 2005). The MBR presents good diffusion and high activity per unit volume. Invertase, in its soluble form, can be used if the chosen UFM has an adequate molecular weight cut-off (MWCO). As invertase (MW 200kDa) is the main component in the process, this study focused on the role of UFM MWCO on continuous sucrose hydrolysis performed in an MBR.

\section{MATERIAL AND METHODS}

Invertase (lyophilized powder containing an activity of $364 \mathrm{U} / \mathrm{mg}_{\mathrm{dw}}$ where $1 \mathrm{U}=1 \mu \mathrm{mol}_{\text {gluc }} / \mathrm{min}$ at $\mathrm{pH} 5.0$ and 30 ${ }^{\circ} \mathrm{C}$ ) was purchased from FLUKA ${ }^{\mathbb{B}}$ (St. Louis, MO, USA) and PBGC polyethersulfone UF membranes (MWCO: $10 \mathrm{kDa}, 30 \mathrm{kDa}, 50 \mathrm{kDa}$ and $100 \mathrm{kDa})$ were purchased from MILLIPORE ${ }^{\circledR}$ (Bedford, MA, USA); the $20 \mathrm{kDa}$ UF membrane (FS61PP/DDS fluoropolymer) was purchased from DOW DENMARK (Nakskov, Denmark). All of the other chemicals were of analytical grade. Tests were performed in a $10 \mathrm{mLEnzyme} \mathrm{MBR} \mathrm{(BIOENGINEERING}$ AG, Wald, Germany), previously described by Tomotani, Neves, and Vitolo (2005).

Continuous tests were performed in the MBR in duplicate using $10 \mathrm{~mL}$ of buffer $(0.05 \mathrm{M}$ acetic acid/acetate solution at $\mathrm{pH} 5.0)$ containing soluble invertase $\left(1.53 \times 10^{-}\right.$ $\left.{ }^{5} \mathrm{mg}_{\mathrm{dw}} / \mathrm{mL}\right)$. The reactor was coupled to different UF membranes $(10 \mathrm{kDa}, 20 \mathrm{kDa}, 30 \mathrm{kDa}, 50 \mathrm{kDa}$, and $100 \mathrm{kDa})$ and fed continuously with a $200 \mathrm{mM}$ sucrose solution at a feeding rate of $10 \mathrm{~mL} / \mathrm{h}$ ( $1 \mathrm{~h}$ residence time). The reaction was performed for $30 \mathrm{~h}$ at $45^{\circ} \mathrm{C}$, agitated at $140 \mathrm{rpm}$. During tests, reactor internal pressure remained constant at 0.7 bar. Aliquot samples taken every hour from the outlet solution were measured for total reducing sugar (glucose plus fructose) concentration, expressed as $\mu \mathrm{mol}$ of glucose using the conventional Somogyi-Nelson method (Tomotani, Neves, Vitolo, 2005). Invertase activity was expressed as $\mu \mathrm{mol}_{\mathrm{gluc}} / \mathrm{min} . \mathrm{mg}_{\mathrm{dw}}$.

\section{RESULTS AND DISCUSSION}

Figure 1 shows that a steady state was attained in all tests although its start time differed according to membrane MWCO. Steady state was seen achieved at reaction start with the 10kDa UFM; however it occurred abruptly after $10 \mathrm{~h}$ continuous feeding with the other UF membranes.

A flow process is considered in a steady-state regimen when conditions at all points of the reaction medium remain constant as time changes. Estimates from Figure 1 show at $\mathrm{t} \geq 10 \mathrm{~h}$ that mean values of the logarithm of specific invertase activity were 3.8, 2.6, 2.7, 2.5 and 2.5 for the $10 \mathrm{kDa}, 20 \mathrm{kDa}, 30 \mathrm{kDa}, 50 \mathrm{kDa}$ and $100 \mathrm{kDa}$ UFM's, respectively.

All UFMs presented different cut-off parameters. The different $\log \left(\mathrm{r}_{\mathrm{sp}}\right)$ values might have resulted from differences in invertase adsorption intensity on each membrane due to the fact that the enzyme molecules and the membrane surface/matrix have charged chemical groups. The higher the membrane cut-off, the more deeply into the polymeric matrix the enzyme molecules may insert themselves. This could cause structural stress on the overall invertase molecule, which could be directly reflected on its active site, which, in turn, could cause conformational and/or steric constraints. All these effects, in the end, would lead to a less efficient sucrose-invertase interaction. There could also be an electrostatic charge interaction between ionized groups of both invertase and the membrane surface/matrix. The reduction in enzymesubstrate interaction, occurring inside the catalytic site of invertase, may be an intermediary step in sucrose hydrolysis which involves the appearance of a positively charged fructosyl group (Vitolo, 2004). This ion could have its positive charge partially neutralized by the negatively charged groups of the matrix, thus reducing its affinity for water molecules. As a consequence, fructosyl could remain longer inside the catalytic site of invertase, causing a reduction in its turnover number, which, in the end, leads to a reduction in overall specific invertase activity. Prevot-D'Alvise et al. (2004) observed that charges present on both the enzyme (in their case, a commercial protease known as Delvolase ${ }^{\circledR}$ produced by DSM Food Specialties, Seclin, France) and the membrane (Carbosep, M5-tubular $\mathrm{ZrO}_{2}$ membrane, produced by Setric Genie Industriel, France) could cause an adsorptive interaction between them, reducing the hydrolysis capability of the protease. Regarding the variation in invertase specific activity against UF membrane cut-off, $r_{\mathrm{sp}}$ decreased as UFM cut-off increased (Table I). Therefore, selecting a UFM with a cut-off lower than enzyme molecular weight (MW) is a required condition but it does not guarantee the highest catalytic activity. In general UFM screening must be performed for any enzyme used in a membrane reactor considering as a limit a UFM cut-off just below enzyme MW. In this work, at first glance, a 100-150kDa UFM was chosen instead of a $10 \mathrm{kDa}$ one, in order to deal with an invertase MW of $200 \mathrm{kDa}$.

Finally, the chemical nature of the UFM seems to have an effect on invertase $r_{s p}$. Table I shows the fluoropolymer UFM (cut-off $=20 \mathrm{kDa}$ ) attaining an $\mathrm{r}_{\mathrm{sp}}$ 
equal to $398 \mu \mathrm{mol}_{\text {gluc }} / \mathrm{min} \cdot \mathrm{mg}_{\mathrm{dw}}$, i.e., a value $20 \%$ lower than that attained with a $30 \mathrm{kDa}$ polyethersulfone UFM. If cut-off were the only parameter affecting invertase specific activity, this $r_{\mathrm{sp}}$ value would have been between 501 and $6310 \mu \mathrm{mol}_{\text {gluc }} / \mathrm{min} \cdot \mathrm{mg}_{\mathrm{dw}}$. Therefore, a coupled effect of both the cut-off value and chemical nature of the UF membrane should be considered for any kind of enzyme used in a membrane reactor.

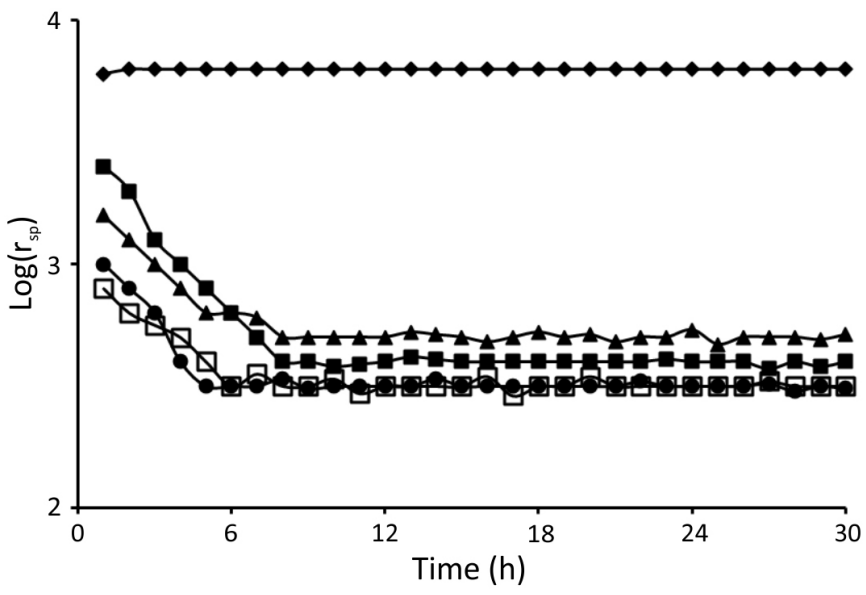

FIGURE 1 - Variation in the logarithm of invertase specific activity $\left(\mathrm{r}_{\mathrm{sp}}\right)$ during continuous hydrolysis of sucrose performed in a membrane reactor coupled to different UF membranes of $10 \mathrm{kDa}(\bullet), 20 \mathrm{kDa}(\boldsymbol{\square}), 30 \mathrm{kDa}(\boldsymbol{\Delta}), 50 \mathrm{kDa}(\square)$ and $100 \mathrm{kDa}(\mathbf{O})$.

TABLE I - Variation in invertase specific activity $\left(\mathrm{r}_{\mathrm{sp}}\right)$ and the corresponding logarithm of $r_{\mathrm{sp}}$ for UF membrane cut-off values

\begin{tabular}{lccccc}
\hline Cut-off & $\mathbf{1 0}$ & $\mathbf{2 0}$ & $\mathbf{3 0}$ & $\mathbf{5 0}$ & $\mathbf{1 0 0}$ \\
\hline $\log \left(\mathrm{r}_{\mathrm{sp}}\right)$ & 3.8 & 2.6 & 2.7 & 2.5 & 2.5 \\
$\mathrm{r}_{\mathrm{sp}}\left(\mu \mathrm{mol}_{\mathrm{gluc}} / \mathrm{min} \mathrm{mg}_{\mathrm{dw}}\right)$ & 6310 & 398 & 501 & 316 & 316 \\
\hline
\end{tabular}

\section{CONCLUSION}

The fluoropolymer membrane $(20 \mathrm{kDa})$ permitted lower specific activity than the polyethersulfone $(30 \mathrm{kDa})$ UFM. It was clear that both cut-off and the chemical nature of the UF membrane affected specific invertase activity.

\section{ACKNOWLEDGMENTS}

Financial Support was provided by Fapesp (Fundação de Amparo à Pesquisa do Estado de São Paulo), Brazil. The authors would like to thank Philip Barsanti for his invaluable and constructive assessment of the manuscript.

\section{REFERENCES}

NISHA, S.; KARTHICK, A.S.; GOBI, N. A review on methods, application and properties of immobilized enzyme. Che. Sci. Rev. Lett., v.1, p.148-155, 2012.

PREVOT-D'ALVISE, N.; LESUEUR-LAMBERT, C.; FERTIN-BAZUS, A.; FERTIN, B.; DHULSTER, P.; GUILLOCHON, D. Continuous enzymatic solubilization of alfafa proteins in an ultrafiltration reactor. Enzyme Microb. Technol., v.34, p.380-391, 2004.

TOMOTANI, E.J.; VITOLO, M. Inverted sugar syrup attained from sucrose hydrolysis using a membrane reactor. Braz. J. Pharm. Sci., v.46, p.571-577, 2010.

TOMOTANI, E.J.; NEVES, L.C.M.; VITOLO, M. Oxidation of glucose to gluconic acid by glucose oxidase in a membrane bioreactor. Appl. Biochem. Biotechnol., v.121, p.149-162, 2005.

VITOLO, M. Invertase. SAID, S., PIETRO R.C.L.R. (Eds.). Enzymes as biotechnological agents. Ribeirão Preto: Leggis Summa, 2004. p.207-221.

Received for publication on $27^{\text {th }}$ March 2013 Accepted for publication on $14^{\text {th }}$ November 2013 
